\title{
DE-DEMOKRATIZÁCIÓ MAGYARORSZÁGON A DEMOKRÁCIAINDEXEK FÉNYÉBEN
}

\author{
Benedek István \\ (MTA TK PTI; ELTE ÁJK PDI)
}

\author{
Tanulmány beérkezése: 2018. 12. 18., \\ opponálás: 2018. 12. 20. - 2019. 01. 28., véglegesités: 2019. 04.27.
}

\section{ÖSSZEFOGLALÓ}

\begin{abstract}
A demokratizáció harmadik hullámának nyitányát jellemző üdvtörténeti és optimista hangvétel az 1990-es évek végére lecsengett, helyette a demokráciák és a zárt autoriter rendszerek közötti szürke zóna egyre aprólékosabb felfedezése következett. Ehhez kapcsolódóan a hazai politikatudomány egyik legaktuálisabb kérdése, hogy hazánk - különösen az elmúlt évtized változásai nyomán - vajon hol helyezhető el ebben a rendszertani mezőben? A helyzetértékelést nehezíti, hogy a különféle demokráciaelméletek, az azokhoz csak lazán kapcsolódó demokráciaindexek múfaja, illetve a számtalan rezsimterminológia és besorolási kísérlet jelentősen különbözik egymástól mind az előfeltevéseiket, mind a kritériumrendszereiket, illetve általában a demokrácia (sőt, a politika) vélelmezett célját, értelmét vagy múködését tekintve. Jelen tanulmányban a hazai de-demokratizálódás legfőbb vonásait és a leginkább sérült területeket szeretném összegezni a legfontosabb demokráciaindexek segítségével, annak reményében, hogy ezzel hozzájárulhatok a helyzet alaposabb megértéséhez.
\end{abstract}

Kulcsszavak: demokrácia @ de-demokratizáció - demokráciaindexek rezsimvita

Az elmúlt évtizedben a hazai politikai berendezkedés természetváltozását, mint egy sebesen mozgó célpontot a - rendszer részeként maga is komoly kihívások elé kerülő - hazai politikatudomány igyekezett lekövetni, feldolgozni és regionális, globális kontextusba ágyazni. Ezáltal egy nagyon jelentős és látványos, a publicisztikák szintjén is markánsan megjelenő rezsimvita alakult ki, amely mellett Magyarország (és a tágabb régiónk) kétes értékű „felértékelödését" lehet tapasztalni a nemzetközi tudományos és politikai diskurzusokban. Hazánk a demokrácia minősége súlyos és rapid romlásának, azaz a zajos demokratikus visszacsúszás és az autokratizáció jelenségének lett nemzetközi szinten is széles körben ismert kurrens példája. Már a hazai vita részletesebb bemutatása is külön tanulmányt igényelne, itt csupán jelezni szeretném, hogy a különféle modellek annyiban egységesek, hogy a demokrácia tartalmi ele- 
meinek kisebb-nagyobb mértékú kiüresedésére mutatnak rá. Ezzel pedig - és ebben már különböznek - megnyitják a lehetőséget vagy

a) egy meglehetősen „leértékelt” demokráciafelfogás felé (Körösényi, 2015, 2017; Csizmadia, 2017), amely bár regisztrálja a demokratikus keretek tartalmi kiüresedésének folyamatát, a hazai politikai rendszert a demokráciák formális keretei között értelmezi; ${ }^{1}$

b) a demokratikus és autoriter elemek keveredéseként értelmezett hibrid rezsimekre jellemző hibridizáció (Gyulai, 2017) és a - korlátozottan, de - versengő autoriter rezsimek (Levitsky-Way, 2002, 2010) irányába (Bozóki-Hegedűs, 2017; Filippov, 2018; Szűcs, 2018; Böcskei, 2019);

c) a választásokra már csak kiüresített homlokzatként (façade) tekintő, a de-demokratizáció ${ }^{2}$ mértéke nyomán már deklaráltan az autokráciák világához sorolt választási autokrácia (Schedler 2002, 2013) és azzal rokon modellek felé (Ágh, 2015, 2019; Kornai, 2015; Antal, 2019a, 2019b; Unger, 2018; Tóth, 2019).

A különféle szinteken zajló hazai vita súlypontja - különösen a 2018. áprilisi választások után - egyértelmúen a két utóbbi álláspont közé került. Az már régóta nem kérdés, hogy jelentősen és szisztematikusan torzultak a politikai versengés feltételei, az viszont igen, hogy vajon ezek nyomán egyáltalán beszélhetünk-e még valódi versengésről, vagy a játéktér már annyira egyenlőtlen, hogy érdemesebb lenne választási vagy „hegemón” (Tóka, 2018) autokráciáról beszélni. A rezsim természete kapcsán a fő kérdés mára az lett, hogy vajon mekkorára szúkült a politikai váltás valódi esélye, valamint mi az értelme és a funkciója a választásoknak: csupán a hatalom teljesen kiüresített önlegitimáló aktusa és díszlete, vagy ennél valamelyest több és a mindenkori ellenzék számára a nyilvánvaló versenyhátrányokkal együtt is érdemi győzelmi eséllyel kecsegtető lehetőség. Úgy tûnik, hogy a folyamatosan mozgásban lévő Orbán-rezsim jelentôs lépéseket tett az előbbi opció kiteljesítése felé, és bár a demokratikus váltás esélyével továbbra is számolhatunk (amely persze nem csak választások keretében történhet meg), az elmúlt évtized súlyos de-demokratizációs folyamata nyomán azzal is szembe kell néznünk, hogy nem csupán a két stáció közötti billegés fázisának fájdalmas mindennapjait éljük, hanem akár már túl is lehetünk azon.

A helyzetértékelés és így a rezsimvita egyik kitüntetett szintje a demokráciaindexek és a különféle rangsoroló intézetek jelentéseinek világa. Ezek között - ahogyan látni fogjuk - egyrészt szintén előbukkannak a választási autokrácia, hibrid rezsim, választási demokrácia, teljes értékú vagy liberális demokrácia stb. kifejezések, amelyek mögöttes tartalmain viszont még „múfajon belül" sincs egyetértés. Jelen tanulmányban a demokráciaindexek múfaját áttekintve kívánok egyfelől egy hasznos és "feljövőben lévő" elemzési eszközkészletet részletesebben bemutatni, másfelől a hazai adatokra és trendekre fókuszálva szeretnék magam is hozzájárulni a jelzett rezsimvitához. Utóbbi kapcsán 
jelen tanulmányban igyekszem meggyőzően alátámasztani a demokráciaindexek segítségével azt az álláspontot, miszerint az Orbán-rezsim jelenlegi állapota nem összeegyeztethetô a pluralista demokrácia (dahli) koncepciójával, méghozzá utóbbi hazai feltételeinek érdemi és rendszerszintű sérülése miatt. Másfelől szeretném azt is bemutatni, hogy a jellemzően jelentős fáziskésésben lévő indexek alkalmasak „legalább” a hibridizációs álláspont megerősítésére, de jóval súlyosabb következtetések is kiolvashatóak belőlük. Ezen a ponton szeretném végezetül bemutatni a leginkább sérült területeket, amelyek a politikai versengés minimálisra szorításának különféle dimenzióit takarják, és így még pontosabb megállapításokra adnak lehetőséget a továbbiakban.

\section{ELŐZETES MEGFONTOLÁSOK}

A demokráciaindexek műfajának ismertetését három, a képviseleti demokráciák minőségének értékelése kapcsán valamelyest alulexponált problémakör felvillantásával kezdem. Elsőként a demokrácia valamint a szabad és tisztességes választások téves megfeleltetésének problémáját a - Terry Karl nevéhez köthető - (téves) elektorializmus (fallacy of electoralism) kifejezéssel szeretném megvilágítani. A probléma abban áll, hogy a Schumpeter nyomán a demokráciát túlságosan leszúkítő elgondolások „a választási küzdelmet a demokrácia minden más dimenziója elé helyezve ignorálhatják azt a tényt, hogy a többpárti választások, még ha valóban versengőek is, mégis érdemben zárhatják ki a lakosság jelentős részét a hatalomért vagy az érdekeik érvényesítéséért folytatott küzdelemből, továbbá a döntéshozatal jelentős területei eshetnek kívül a választott tisztségviselók látó- vagy hatáskörén" (Diamond, 1996: 22.). Azaz, Sartorival szólva (1970) az elméletek (absztrakció) szintjei közötti elmozdulás, így a „fogalmi nyújtás” (conceptual stretching) kockázata léphet fel, hiszen még a demokrácia procedurális-minimalista megközelítései sem elégszenek meg pusztán a (versengô) választások kritériumával, hanem azt számtalan polgári szabadságjoggal egészítik ki (Collier-Levitsky, 1997). Ezért a szúken értelmezett választások pillanatain túlmutató, az azok közötti időszak és a fennálló rendszer egészének folyamatait vizsgáló elemzések érvényesebb és hasznosabb megállapításokkal járhatnak. Nem véletlen, hogy az elmúlt évtizedek demokráciavitái során a formális és statikus szemlélet helyét fokozatosan átvette a demokrácia múködésére fókuszáló dinamikus megközelítés (Ágh, 2012).

Másodsorban szeretném kiemelni azt a tényt, hogy a demokráciához szükséges elemek (amelyekről persze folyamatosan vita zajlik) mindegyikének egyszerre és egyúttal külön-külön is kielégítő mértékben kell jelen lennie (teljesülnie) egy demokratikus rezsimbesorolás esetén (metafeltétel). A poliarchia (pluralista demokrácia) modelljének kifejtésekor Robert A. Dahl is jelezte, hogy „csak akkor nevezhető egy ország demokratikusnak, ha rendelkezik az összes politikai intéz- 
ménnyel, amely szükséges a demokráciához", továbbá az általa felsorolt kritériumok (intézmények) mindegyikének egyszerre kell „relatíve magas” (vö. a következő bekezdés) szinten teljesülnie, persze az „emberi kapacitásokon belül maradva" (Dahl, 1998: 101.; Dahl, 2006: 84-87.). Ugyanezt a gondolatmenetet fogalmazza meg a későbbiekben Andreas Schedler is a „demokratikus választás láncolata” kapcsán, amelyben a demokrácia elemei „egy metaforikus láncolatot alkotnak, amely mint egy valóságos lánc, csak addig létezik, ameddig az elemek közötti összes kapcsolat megmarad teljesnek és töretlennek" (Schedler, 2002: 40.).

A harmadik problémakör már a mérhetőség kérdésének alapvető dilemmáit takarja. Az értékelések kapcsán a hibrid rezsimek világához hasonlóan, maguk a kutatók is szürke zónába érkeznek, mivel az elemkonstellációkról szóló vitán túl annak eldöntése, hogy az egyes elemek terén mi számít egy megközelítés (úgy a kutatók, mint egy-egy intézet esetén) „elégséges mértékű teljesülésnek" (vagy „érdemi sérülésnek”), egy bizonyos mértékü, a múfaj jellegéből adódó önkényességhez vezet. Hiszen bár egy-egy elem ideáltipikus mértékú teljesülésének vagy hiányának a lehetősége (szinte) elképzelhetetlen, a két szélsőség között viszont számtalan árnyalat létezik - amelyet a rezsimek dinamikus jellege még tovább bonyolít. Az elemek teljesülésének lehetséges elméleti fokozatai, valamint a rezsimek ezek közötti - akár inkrementális jellegü - múködésbeli változásainak értékelése (klasszifikáció) és a meglévő (sok esetben szűkös) kategóriák közötti választások során az értékelést végző intézetek és kutatók nem kerülhetnek el egy bizonyos szintü önkényességet (és így az eredmények bizonyos fokú relativizálhatóságát), amelyet csak fokozott mértékű transzparenciával lehet valamelyest ellensúlyozni.

\section{A DEMOKRÁCIAINDEXEK ÉS MAGYARORSZÁG ÉRTÉKELÉSE}

Bár a demokráciaindexek témakörében hazai munkák nem igazán készültek a már jelzett Ágh-tanulmányt (2012), illetve egy jogállamiságra fókuszáló cikket (Jakab-Lőrinc, 2016) leszámítva, azonban a témakör a nemzetközi politikatudományban jelentősnek és kutatottnak számít (Munck-Verkuilen, 2002; Diamond-Morlino, 2004; Morlino, 2004; Campbell, 2008; Collier-Levitsky, 2009; Møller-Skaaning, 2010; Ringen, 2011; Coppedge et al., 2011; Högström, 2013; Völkel, 2015; Diamond et al., 2016; Geissel et al., 2016). A demokrácia schumpeteri elgondolására (2003) építő minimalista megközelítések alapvetően a (pártok közötti) versengés és az általános választójogra épülő részvétel két komponensét vizsgálják. Ehhez képest többletet jelent a dahli modell (1971), amelyben a nyilvánosságnak, a szerveződés szabadságának és egyéb intézményeknek kitüntetett szerepe lesz abban, hogy a vezetők valóban reszponzívak legyenek a vezetettek irányába. Ahogyan idővel újabb és újabb elemek és elvárások kerültek a modellekbe, úgy vált egyre kevésbé tarthatóvá a rezsimek bináris fel- 
osztása demokráciákra és diktatúrákra, és egyre inkább a demokráciák minősége került a fókuszba. Részben ennek a folyamatnak az oka, részben pedig következménye a köztes zónával foglalkozó hibrid-irodalom felfutása. ${ }^{3}$

Bár a szűkebb demokráciadefiníciókon való túllendülés - különösen az európai megközelítések esetében - elterjedtnek mondható, azért a magasabb szinten aggregált és a demokrácia szúkebb (thin) felfogásával dolgozó amerikai Polity és Freedom House (FH) indexei továbbra is széles körben használatosak. Idővel azonban egyre több tényezőt vontak be a kutatásokba: például szocioökonómiai aspektusokat, a politikai és civil társadalmi részvétel dimenzióit, a politikai kultúrával kapcsolatos kritériumokat, az állam és a közigazgatás átláthatóságára és múködésére fókuszáló dimenziókat. Míg az indexeket tartalmazó képzeletbeli skálának ugyancsak inkább a „minimalistább” oldalán helyezkedik el a Stockholm központú International IDEA indexe (IDEA GSoD), addig a demokrácia deklaráltan tágabb (thick) definíciójával dolgozó London központú Economist Intelligence Unit Democracy Indexe (EIU) és a német think-tank Bertelsmann Stiftung Transformation Indexe (BTI) jelenti a másik oldalt. Ezek mellett mindenképpen ki kell térni a göteborgi Varieties of Democracy (V-Dem) projektjére, amely kifejezetten a múfajt jellemző terminológiai káosz kezelésére jött létre (Coppedge et al., 2011), megalkotva a saját, indikátorok százaiból álló „történeti, multidimenzionális, diszaggregált és transzparens" megközelítését. A mutatókból a kutatók maguk állíthatják össze a saját demokráciadefiníciójuknak megfelelő indexeket, de vannak előre elkészített alaptípusok is.

A vizsgált indexek közötti különbségek kapcsán meg kell említeni az időbeli lefedettséget, amely a közel 15 éves tartománytól (EIU, BTI), több évtizeden át (IDEA, FH) egészen évszázados távlatokat is jelenthet (Polity, V-Dem). Az adatok tekintetében jellemzően a projektben résztvevő szakértők értékelése a döntő, bár például az EIU esetében megjelennek közvélemény-kutatási adatok is, ugyanakkor ezek elég kevés ország kapcsán érhetőek el. Meg kell jegyezni azt is, hogy a demokráciaindexeket, illetve a kapcsolódó jelentéseket és rangsorokat kiadó jelentősebb intézményeket különösen jellemzi az a fajta "tehetetlenségi erö", amely általában is észlelhető a nagy szervezeteknél. Míg egy-egy kutató sokkal gyorsabban és szabadabban reagálhat újabb jelenségekre és a bekövetkezett változásokra, addig ezeknek a nagy intézményeknek a múködése eleve hosszadalmas, rengeteg egyeztetés, regionális és globális kiigazítás után születnek meg az előző évről szóló - anyagok, ráadásul kötik őket a saját korábbi eredményeik (pontszámaik) is. Így túl azon, hogy egyfajta "fáziskésés” jellemzi ezeket az intézeteket, sok tekintetben „kötött pályán” is mozognak - amely persze egyúttal előnyös a megbízhatóság és az összehasonlítás szempontjából. Ezek az intézetek tehát egyfajta „nehézlovasságnak”, míg az olyan kutatók, mint Wolfgang Merkel vagy Laza Kekic (akik a BTI és az EIU módszertanához járultak hozzá) a „könynyưlovasságnak" tekinthetők, akik gyorsabban tudnak reagálni és adott esetben új szemléleteket kidolgozni. 
Freedom House (FH) - Freedom in the World (FiW)

Az 1972 óta létező Freedom in the World (FiW) alapvetően a politikai jogok (PR) és a polgári szabadságjogok (CL) kiterjedtségét vizsgálja, mindkét elem esetében 1-től 7-ig terjedő skálán értékeli az országokat, az 1-es pontszám esetén a leginkább „szabadnak” (vagy demokratikusnak), míg a 7-es esetén a legkevésbé szabadnak (vagy a leginkább autoriternek). Már a terminológia is jelzi, hogy alapvetően a hidegháborús narratíva (szabad és kommunista világ) bináris felosztásában közelíti meg a demokráciát. A két kategória pontszámainak számtani átlaga alapján három végső rezsimklasszifikáció lehetséges: „szabad” (12,5), „félig szabad” (3,0-5,0) és „nem szabad” (5,5-7). Magyarország a (2018-as évről szóló) 2019-es jelentésben immáron a polgári szabadságjogok tekintetében is „3-as" besorolásara csúszott vissza, így az ország státusza "félig szabad" lett, amely utoljára 1984 és 1989 között volt ugyanígy.

1. táblázat. A Freedom House Freedom in the World pontrendszere

\begin{tabular}{lc}
\hline Politikai jogok (PR) & \\
\hline Összpontszám & PR besorolás \\
\hline $36-40$ & 1 \\
$30-35$ & 2 \\
$24-29$ & 3 \\
$18-23$ & 4 \\
$12-17$ & 5 \\
$6-11$ & 6 \\
$0-5$ & 7 \\
\hline
\end{tabular}

\begin{tabular}{lc}
\hline \multicolumn{2}{l}{ Polgári szabadságjogok (CL) } \\
\hline Összpontszám & CL besorolás \\
\hline $53-60$ & 1 \\
$44-52$ & 2 \\
$35-43$ & 3 \\
$26-34$ & 4 \\
$17-25$ & 5 \\
$8-16$ & 6 \\
$0-7$ & 7 \\
\hline
\end{tabular}

Összesen hét alkategóriára osztódik a két elem, az alkategóriák 3-4 indikátorra épülnek (összesen 25) és mindegyiket 0 és 4 pont között lehet osztályozni. Ezek a pontszámok összeadódva adják ki a két fő kategória értékét, azonban az alkategóriák pontszámait csak 2006 óta teszik közzé, amely miatt korábban kritika tárgya volt, hogy az értékelések nem átlátható módon jönnek létre (Munck-Verkuilen, 2002). Emellett az index mind a konceptualizáció, mind a módszertan tekintetében változott az idők során (Diamond et al., 2016), igaz ez nem a tanulmányban vizsgált elmúlt évtizedet érinti. Továbbá nem csak a hidegháború vége előtt, hanem manapság is joggal merülhet fel az - Egyesült Államok által finanszírozott - intézettel szemben az elfogultság vádja (BollenPaxton, 2000; Denk, 2013; Steiner, 2014; Bush, 2017), és azt is tudni lehet, hogy regionális bontásban erősen favorizálja Nyugat-Európát (Högström, 2013).

A legutóbbi évekig a politikai jogok feleltek az ún. választási demokrácia kiterjedtségének méréséért, amely a módszertan szerint azt jelenti, hogy „az ál- 
lampolgárok maguk választhatják meg vezetőiket és képviselőiket, méghozzá szabad és tisztességes választások keretében, széles részvétel mellett". ${ }^{5}$ A választási demokráciát eddig akkor "hitelesítették”, ha a választási eljárás alkategóriájában legalább 7 pontot (a lehetséges 12-ből) ért el egy ország, miközben a politikai jogok kategóriájában legalább 20 pontot (a lehetséges 40-ből). A 2017es jelentés módszertanában már hozzátették azt a feltételt is, hogy a másik fő kategória (polgári szabadságjogok) 60 lehetséges pontszámából legalább 30-at érjen el egy adott ország. Magyarország elmúlt egy évtizedének értékelésbeli változásai a 2. táblázatban olvashatók, amelyből jól látszik, hogy a kritériumok rendszerszintú és érdemi sérülése következett be, leginkább a nyilvánosság szférájában (D), legkevésbé pedig a szorosabban vett politikai jellegúnek kevésbé tekinthető egyéni jogok $(\mathrm{G})$ terén.

2. táblázat. Magyarország értékélése a Freedom in the World alapján

\begin{tabular}{|c|c|c|c|c|c|}
\hline $\begin{array}{l}\text { Kate- } \\
\text { góriák }\end{array}$ & Alkategóriák & 2009 & 2019 & $\begin{array}{l}\text { 2019-es } \\
\text { arány* }\end{array}$ & $\begin{array}{l}\text { Csökkenés } \\
\text { mértéke* }\end{array}$ \\
\hline \multirow{4}{*}{ 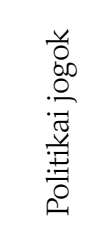 } & A) Választási eljárás (12 p.) & 12 & 9 & $75 \%$ & $-25 \%$ \\
\hline & $\begin{array}{l}\text { B) Politikai pluralizmus } \\
\text { és részvétel (16 p.) }\end{array}$ & 15 & 11 & $69 \%$ & $-25 \%$ \\
\hline & C) Kormányzati múködés (12 p.) & 10 & 7 & $58 \%$ & $-25 \%$ \\
\hline & Kategória összesen (40 p.) & 37 & 27 & $68 \%$ & $-25 \%$ \\
\hline \multicolumn{2}{|c|}{ Kategória 1-7 pont között } & 1 & 3 & & \\
\hline \multirow{5}{*}{ 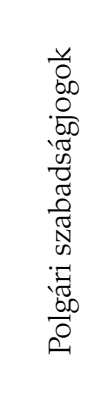 } & $\begin{array}{l}\text { D) Szólás- és vallásszabadság, illetve a } \\
\text { nem vallásos meggyőződések sza- } \\
\text { badsága (16 p.) }\end{array}$ & 16 & 10 & $69 \%$ & $-38 \%$ \\
\hline & $\begin{array}{l}\text { E) Egyesülési és szervezeti szabadság } \\
(12 \text { p.) }\end{array}$ & 12 & 10 & $83 \%$ & $-17 \%$ \\
\hline & F) Jogállamiság (16 p.) & 13 & 10 & $63 \%$ & $-19 \%$ \\
\hline & $\begin{array}{l}\text { G) Személyi szabadság és egyéni jogok } \\
(16 \text { p.) }\end{array}$ & 14 & 13 & $81 \%$ & $-6 \%$ \\
\hline & Kategória összesen (60 pont) & 55 & 43 & $72 \%$ & $-20 \%$ \\
\hline \multicolumn{2}{|c|}{ Kategória 1-7 pont között } & 1 & 3 & & \\
\hline \multicolumn{2}{|c|}{ Összesen (100 pont) } & 92 & 70 & $70 \%$ & $-22 \%$ \\
\hline
\end{tabular}

* Az elérhető összpontszámok arányában.

A módszertan szerint az FH FiW igyekszik megkülönböztetni a választási demokrácia és a liberális demokrácia kategóriáit, azonban míg az előbbi esetén létezik a fent ismertetett eljárás, addig utóbbiról csupán annyit tudunk meg, hogy „a polgári szabadságjogok szélesebb körü, robosztusabb teljesítését követeli meg”. 
A módszertan szerint a „szabad” országok tekinthetők liberális demokráciáknak, míg a "félig szabad” országok csupán „választási demokráciáknak”. Mivel az FH igen robosztus kategóriákkal, illetve könnyen teljesíthető és alapvetően formális, procedurális kritériumokkal dolgozik, azt lehet mondani, hogy az intézet meglehetősen "megengedő" demokráciafogalmat használ, amely kapcsán a "szabad” besorolás valójában nem garantálja a liberális demokráciát, míg a "félig szabad” értékelés adott esetben nem demokráciákat minősíthet választási demokráciának. Végezetül meg kell jegyezni, hogy a médiához kapcsolódó $F H$-elemzések (Freedom of the Press, Freedom on the Net) kiemelkedő színvonalúak, ugyanakkor azokat nem kapcsolják össze a többi jelentéssel.

\section{Freedom House (FH) - Nations in Transit (NiT)}

Az amerikai intézet kifejezetten az átmeneti országok demokratizációs folyamatai vizsgálatának céljával indította el 2005-ben a Nations in Transit (NiT) nevú projektjét. A FiW főkategóriájánál már megszokhatott 1-7-es skálán értékelik az egyes ország-jelentések a különféle alkategóriákat (4. táblázat), míg az egyes területekhez tartozó részpontszámok nyomán megszülető összesített demokráciapontszámok különféle rezsimkategóriákhoz rendelhetőek (3. táblázat).

3. táblázat. A Nations in Transit végső pontrendszere és rezsimdefiníciói

\begin{tabular}{|c|c|c|}
\hline $\begin{array}{l}\text { Inter- } \\
\text { vallum }\end{array}$ & Elnevezés & Definíció \\
\hline $1-1,99$ & \multirow{2}{*}{$\begin{array}{l}\text { Konszolidált } \\
\text { demokrácia }\end{array}$} & A leginkább liberális demokráciák. \\
\hline $2-2,99$ & & $\begin{array}{l}\text { A leginkább liberális demokráciák, de - döntően - a korrupció } \\
\text { miatt alacsonyabb pontszámok. }\end{array}$ \\
\hline $3-3,99$ & $\begin{array}{l}\text { Félig } \\
\text { konszolidált } \\
\text { demokrácia }\end{array}$ & $\begin{array}{l}\text { Olyan választási demokráciák, ahol kisebb } \\
\text { rendellenességektől eltekintve alapvetően teljesülnek } \\
\text { a demokratikus kritériumok. }\end{array}$ \\
\hline $4-4,99$ & $\begin{array}{l}\text { Átmeneti } \\
\text { vagy hibrid } \\
\text { rezsim }\end{array}$ & $\begin{array}{l}\text { Olyan választási demokráciák, amelyekben a vezetők } \\
\text { kiválasztása épphogy eléri a minimális elvárásokat, } \\
\text { miközben a demokratikus intézmények gyengék. }\end{array}$ \\
\hline $5-5,99$ & $\begin{array}{l}\text { Félig konszo- } \\
\text { lidált autori- } \\
\text { ter rezsim }\end{array}$ & $\begin{array}{l}\text { A választási demokráciák minimális követelményeinek sem } \\
\text { tudnak igazán megfelelni, jellemzően olyan országok, } \\
\text { amelyek igyekeznek autoriter jellegüket demokratikus } \\
\text { intézmények és gyakorlatok mögé rejteni. }\end{array}$ \\
\hline $6-7$ & $\begin{array}{l}\text { Konszolidált } \\
\text { autoriter } \\
\text { rezsim }\end{array}$ & $\begin{array}{l}\text { Zárt társadalmak, ahol a diktatúrák megakadályozzák } \\
\text { a politikai versenyt és a pluralizmust, miközben súlyosan } \\
\text { sérülnek a politikai, polgári és emberi jogok. }\end{array}$ \\
\hline
\end{tabular}

Szeretném külön kiemelni, hogy itt explicite is tetten érhető az a tény, miszerint a választási demokrácia fogalma alatt egy meglehetősen megengedő 
értelmû megközelítést kell értenünk az $F H$ esetében, hiszen az „átmeneti és hibrid" rezsimek kategóriáját is ezzel a definícióval jellemzik. Azaz a választási demokrácia koncepciója nem csupán a (konszolidált) liberális demokráciák csökkentett értékû („félig konszolidált”) variánsainak, hanem egyúttal a hibrid rezsimek leírására is szolgál. Magyarország a legfrissebb (2018), azaz a 2017-es évről szóló jelentés szerint a „félig konszolidált demokrácia” kategóriájából a „hibrid rezsim” besorolás felé tart (3,71 ponttal). Ha a rezsimdefiníciókat alaposabban megfigyeljük, akkor azt láthatjuk, hogy az utóbbi években a pontszámból következő „félig konszolidált demokrácia” kategóriájának jellegzetességei (a civil társadalom független és aktív; a média alapvetően független és sokszínư; a kormányzás transzparens és elszámoltatható stb.) kevéssé egyeznek meg a hazai állapotokkal. Valószínúleg az újabb jelentésben már az "átmeneti vagy hibrid rezsim” kategóriába kerül át az ország (amelyben versengő, de nem okvetlenül szabad vagy fair választások vannak; a civil társadalom alapvetôen független, de jelentős kormányzati nyomások is érhetik; a média alapvetően független és sokszínú, de a napi gyakorlatban komoly rendellenességek figyelhetőek meg stb.). Ugyanakkor mivel több alkategória (kormányzás demokratikus minősége, független média, korrupció) pontszáma is már egyenesen az 5-5,99-es sávot („félig konszolidált autoriter rezsim”) közelíti, illetve a 2018-ra vonatkozó jelentésben el is érheti azt, ezért ha az összes elem (számtani) átlaga nem is éri el a "félig konszolidált autokrácia" szintjét, a demokratikus elemek együttesen és külön-külön is legalább kielégítő mértékú jelenlétének metafeltétele (lásd a bevezetôt) egyértelmúen nem teljesül - így pedig semmiképp sem beszélhetünk demokráciáról. A fő kérdés tehát ezekben a kategóriákban - ahogyan a hazai rezsimvitában is -, hogy Magyarország „"ssupán” hibrid rezsim vagy már autokrácia.

4. táblázat. Magyarország értékelése a Nations in Transit alapján

\begin{tabular}{lcccc}
\hline Kategóriák & 2009 & $\mathbf{2 0 1 8}$ & $\begin{array}{c}\text { 2018-as } \\
\text { arány }\end{array}$ & $\begin{array}{c}\text { Csökkenés } \\
\text { mértéke }\end{array}$ \\
\hline Kormányzás demokratikus minősége & 2,50 & 4,50 & $42 \%$ & $-33 \%$ \\
\hline Választási eljárás & 1,75 & 3,25 & $63 \%$ & $-25 \%$ \\
\hline Civil társadalom & 1,75 & 3,00 & $67 \%$ & $-21 \%$ \\
\hline Független média & 2,50 & 4,50 & $42 \%$ & $-33 \%$ \\
\hline $\begin{array}{l}\text { Helyi önkormányzatiság demokratikus } \\
\text { minősége }\end{array}$ & 2,50 & 3,00 & $67 \%$ & $-8 \%$ \\
\hline $\begin{array}{l}\text { Igazságszolgáltatás intézményrendszere és } \\
\text { függetlensége }\end{array}$ & 1,75 & 3,00 & $67 \%$ & $-21 \%$ \\
\hline Korrupció & 3,00 & 4,75 & $38 \%$ & $-29 \%$ \\
\hline Demokrácia-pontszám & 2,29 & 3,71 & $55 \%$ & $-24 \%$ \\
\hline
\end{tabular}




\section{IDEA International Global State of Democracy (IDEA GSoD)}

A svéd IDEA a demokrácia promotálásával és szaktanácsadással foglalkozik a fejlődő országokban (Ágh, 2012: 63-64.), utóbbiak megértése és ösztönzése céljából pedig jellemzően minimális követelményekből építi fel a demokrácia fogalmát a kutatásaiban. Az IDEA GSoD adatbázisa7 az 1975 és 2017 közötti időszakról nyújt áttekintést különféle attribútumok, komponensek és indikátorok formájában, viszont ezeket nem aggregálja egy végső demokráciaindexbe. Az eddigiektől eltérően nem saját értékelések alapján zajlik a munka, hanem más adatbázisokból gyưjtik össze az információkat, amelyeket az egyes indikátorok korrelációját is figyelembe véve összesítenek (0-1-es skála, 1 pont a legjobb).

Az IDEA abból indul ki, hogy a demokrácia két legfontosabb elve az állampolgári kontroll a döntéshozatal során (és a döntéshozók felett), valamint a politikai egyenlőség (a kontroll gyakorlása során). Azaz a demokrácia a politikai döntések feletti kontrollt egyenlő módon osztja szét, amelyből egyenesen következik a politikai és a polgári jogok tisztelete. Kifejezetten hangsúlyozza, hogy ezek az elvek számtalan formában létezhetnek, így nem az intézményes megoldásokat, hanem a tényleges megvalósulásokat érdemes vizsgálni. Az eddigiekhez képest az IDEA valamelyest szélesebb és analitikusan disztingváltabb spektrummal dolgozik, illetve az alapvetó jogok esetében bizonyos szociális jogok és minimális jóléti dimenziók is - bár meglehetősen minimális mértékben - helyet kapnak.

5. táblázat. Magyarország értékelése az IDEA GSoD alapján

\begin{tabular}{lcccc}
\hline Kategóriák & 2009 & 2017 & $\begin{array}{c}\text { 2017-es } \\
\text { arány }\end{array}$ & $\begin{array}{c}\text { Csökkenés } \\
\text { mértéke }\end{array}$ \\
\hline $\begin{array}{l}\text { Képviseleti kormányzat } \\
\text { demokratikussága }\end{array}$ & 0,78 & 0,67 & $67 \%$ & $-11 \%$ \\
\hline Alapvető jogok & 0,75 & 0,71 & $71 \%$ & $-4 \%$ \\
\hline Kormányzati ellensúlyok & 0,71 & 0,60 & $60 \%$ & $-11 \%$ \\
\hline $\begin{array}{l}\text { Pártatlan és méltányos } \\
\text { közigazgatás }\end{array}$ & 0,66 & 0,60 & $60 \%$ & $-6 \%$ \\
\hline $\begin{array}{l}\text { Politika inkluzivitása* } \\
\text { Átlagolt összpontszám* }\end{array}$ & 0,63 & 0,58 & $58 \%$ & $-5 \%$ \\
\hline
\end{tabular}

* Saját számítás: számtani átlagolás alapján. 


\section{Varieties of Democracy (V-Dem)}

A $V$-Dem ${ }^{8}$ nem csupán a legfrissebb projektnek, hanem a „demokrácia mérésének" legsokoldalúbb megközelítésének is tekinthető. A 2014-ben Staffan I. Lindberg által alapított $V$-Dem Intézet egészen a 18. századig visszamenően elkészített és évente frissített adatbázisa egy jelentős nemzetközi kutatóhálózat közös munkájának köszönhető. A több ezer szakértő bevonásával zajló adatbázis-építés során több, mint 350 indikátorral dolgoznak, amelyeknek nagyjából a fele tekinthető „kemény” (kormányzati és egyéb hivatalos dokumentumokból származó) adatnak, míg a másik felét a szakértők értékelései teszik ki, akik a de jure szemlélettel szemben döntően a de facto politikai múködésmódot vizsgálják. A $V$-Dem szerint a demokráciaindexek mögött húzódó eltérő koncepciók és a magas szinten aggregált elemzések miatt párhuzamos monológok zajlanak, amelyet azzal lehet leginkább kezelni, ha elfogadjuk a lehetséges megközelítések sokszínúségét és megpróbálunk minél kisebb szintû mutatószámokat a lehető leginkább transzparens módon létrehozni: ezeket pedig (kis építőkockánként) számtalan formában illeszthetjük egymásra az aggregálások során. A legmagasabb szinten így a "demokrácia dimenziói” jelennek meg, amelyek külön indexek formájában is elérhetőek, az egyes elemek terén pedig különféle súlyozásokkal figyelnek az együttes teljesülés meta-feltételére.

A végső rezsimbesorolások nem közvetlenül az egyes demokráciadimenziók teljesüléséből következnek, hanem külön indexek jelzik őket, amelyek alapvetően négy típust különböztetnek meg. Magyarország besorolása 2009 és 2019 (2018) között liberális demokráciából (3) választási demokráciára (2) változott, amely a részletesebb, 0-9-es skálán a 8-as pontszámról az 5-ösre („gyenge” választási demokrácia) történő csökkenést jelent.

6. táblázat. A Varieties of Democracy rezsimtípusai

\begin{tabular}{lll}
\hline Pontszám & Elnevezés & Definíció \\
\hline 0 & $\begin{array}{l}\text { Zárt } \\
\text { autokrácia }\end{array}$ & Nincsenek többpárti választások. \\
\hline 1 & $\begin{array}{l}\text { Választási } \\
\text { autokrácia }\end{array}$ & $\begin{array}{l}\text { De jure többpárti választások, de nem tisztességesek és } \\
\text { szabadok, vagy nem ténylegesen többpártiak, vagy nem } \\
\text { teljesítik a dahli kritériumokat (választási demokráciaindex). }\end{array}$ \\
\hline 2 & $\begin{array}{l}\text { Választási } \\
\text { demokrácia }\end{array}$ & $\begin{array}{l}\text { De facto szabad és tisztességes választások, amelyek } \\
\text { teljesítik a dahli kritériumokat (azaz választási demokráciák), } \\
\text { de nem teljesülnek kielégítő mértékben a liberális } \\
\text { komponensek. }\end{array}$ \\
\hline 3 & $\begin{array}{l}\text { Liberális } \\
\text { demokrácia }\end{array}$ & $\begin{array}{l}\text { De facto tisztességes, szabad és többpárti választások, és a } \\
\text { dahitériumokon túl teljesülnek a liberális komponensek. }\end{array}$ \\
\hline
\end{tabular}


Fontos megjegyezni, hogy a V-Dem többi demokráciaindexe által is felhasznált választási demokrácia (poliarchia) -index az eddigi demokráciafogalmakhoz képest (ám Dahl gondolatmenetéhez hưen) szigorúbb és robosztusabb szemléletével mind a szólásszabadság, mind az alternatív információforrások, mind az egyesülés szabadságának kritériumát átfogóbban vizsgálja, és - amely talán még fontosabb - mindezt nem csupán a választásokra koncentrálva teszi. A legfrissebb (2019), 2018-as évre vonatkozó adatok alapján, a különféle demokráciadimenziókban (0-1 pont között, 1 pont a legjobb) tapasztalható változások azt mutatják, hogy Magyarország a liberális, a részvételi, a deliberatív és az egalitárius demokráciakoncepciókkal semmiképp sem feleltethető már meg (hiszen a lehetséges pontszámok 32-44\%-át éri el). A választási demokráciaindex (amelyben Bosznia-Hercegovina és Koszovó mögött állunk) tekintetében különösen a demokratikus nyilvánosság sérülése a szembeötlő, az összkép pedig jelentős de-demokratizálódást mutat, amely a $V$-Dem rezsimtipológiája esetében a választási autokrácia felé tartó mozgást jelenti.

7. táblázat. Magyarország értékelése a V-Dem Választási demokráciaindexe alapján

\begin{tabular}{lcccc}
\hline Kategóriák & 2009 & $\mathbf{2 0 1 8}$ & $\begin{array}{c}\text { 2018-as } \\
\text { arány }\end{array}$ & $\begin{array}{c}\text { Csökkenés } \\
\text { mértéke }\end{array}$ \\
\hline Egyesülés szabadsága & 0,86 & 0,73 & $73 \%$ & $-13 \%$ \\
\hline Tiszta választások & 0,93 & 0,71 & $71 \%$ & $-22 \%$ \\
\hline $\begin{array}{l}\text { Szólásszabadság és alternatív } \\
\text { információforrások }\end{array}$ & 0,95 & 0,62 & $62 \%$ & $-33 \%$ \\
\hline Választott hivatalok & 1 & 1 & $100 \%$ & 0 \\
\hline Választójog & 1 & 1 & $100 \%$ & 0 \\
\hline$\sum=$ Electoral democracy (polyarchy) index & 0,82 & 0,54 & $54 \%$ & $-28 \%$ \\
\hline
\end{tabular}

8. táblázat. Magyarország értékelése a V-Dem Liberális demokráciaindexe alapján

\begin{tabular}{lcccc}
\hline Kategóriák & 2009 & $\mathbf{2 0 1 8}$ & $\begin{array}{c}\text { 2018-as } \\
\text { arány }\end{array}$ & $\begin{array}{c}\text { Csökkenés } \\
\text { mértéke }\end{array}$ \\
\hline Electoral democracy index & 0,82 & 0,54 & $54 \%$ & $-28 \%$ \\
\hline $\begin{array}{l}\text { Liberal component index } \\
\text { Jog előtti egyenlőség és egyéni szabadság } \\
\text { (jogállamiság) }\end{array}$ & 0,90 & 0,79 & $79 \%$ & $-11 \%$ \\
\hline $\begin{array}{l}\text { Az igazságszolgáltatás, } \\
\text { mint a végrehajtás korlátja }\end{array}$ & 0,91 & 0,79 & $79 \%$ & $-12 \%$ \\
\hline $\begin{array}{l}\text { A törvényhozás, mint a végrehajtás } \\
\text { korlátja }\end{array}$ & 0,88 & 0,63 & $63 \%$ & $-25 \%$ \\
\hline$\sum=$ Liberal democracy index & 0,72 & 0,44 & $44 \%$ & $-28 \%$ \\
\hline
\end{tabular}


9. táblázat. Magyarország értékelése a V-Dem Részvételi demokráciaindexe alapján

\begin{tabular}{lcccc}
\hline Kategóriák & 2009 & 2018 & $\begin{array}{c}\text { 2018-as } \\
\text { arány }\end{array}$ & $\begin{array}{c}\text { Csökkenés } \\
\text { mértéke }\end{array}$ \\
\hline Electoral democracy index & 0,82 & 0,54 & $54 \%$ & $-28 \%$ \\
\hline Participatory component index & 0,70 & 0,59 & $59 \%$ & $-11 \%$ \\
\hline Civil társadalmi részvétel & 0,78 & 0,56 & $56 \%$ & $-22 \%$ \\
\hline Közvetlen szavazási index & 0,32 & 0,35 & $35 \%$ & $+3 \%$ \\
\hline Helyi önkormányzati index & 0,97 & 0,92 & $92 \%$ & $-5 \%$ \\
\hline Regionális önkormányzati index & 0,99 & 0,77 & $77 \%$ & $-22 \%$ \\
\hline$\sum=$ Participatory democracy index & 0,61 & 0,32 & $32 \%$ & $-29 \%$ \\
\hline
\end{tabular}

10. táblázat. Magyarország értékelése a V-Dem Deliberatío demokráciaindexe alapján

\begin{tabular}{|c|c|c|c|c|}
\hline Kategóriák & 2009 & 2018 & $\begin{array}{l}\text { 2018-as } \\
\text { arány }\end{array}$ & $\begin{array}{l}\text { Csökkenés } \\
\text { mértéke }\end{array}$ \\
\hline Electoral democracy index & 0,82 & 0,54 & $54 \%$ & $-28 \%$ \\
\hline Deliberative component index & 0,71 & 0,52 & $52 \%$ & $-19 \%$ \\
\hline $\begin{array}{l}\text { Döntések átlátható és ésszerü igazolása, } \\
\text { * skála: } 0-3\end{array}$ & 1,87 & 1,25 & $42 \%$ & $-20 \%$ \\
\hline Döntések közjóval történő igazolása, ${ }^{*} 0-4$ & 2,65 & 2,83 & $71 \%$ & $+5 \%$ \\
\hline Ellenvélemények tisztelete, ${ }^{*} 0-5$ & 2,77 & 1,64 & $33 \%$ & $-22 \%$ \\
\hline Konzultáció mértéke, ${ }^{*} 0-5$ & 2,55 & 2,19 & $44 \%$ & $-7 \%$ \\
\hline $\begin{array}{l}\text { Társadalmi vita és valódi bevonás a } \\
\text { döntéshozatal során, }{ }^{*} 0-5\end{array}$ & 2,70 & 2,17 & $43 \%$ & $-11 \%$ \\
\hline$\sum=$ Deliberative democracy index & 0,61 & 0,32 & $32 \%$ & $-29 \%$ \\
\hline
\end{tabular}

11. táblázat. Magyarország értékelése a V-Dem Egalitárius demokráciaindexe alapján

\begin{tabular}{|c|c|c|c|c|}
\hline Kategóriák & 2009 & 2018 & $\begin{array}{l}\text { 2018-as } \\
\text { arány }\end{array}$ & $\begin{array}{l}\text { Csökkenés } \\
\text { mértéke }\end{array}$ \\
\hline Electoral democracy index & 0,82 & 0,54 & $54 \%$ & $-28 \%$ \\
\hline Egalitarian component index & 0,85 & 0,68 & $68 \%$ & $-17 \%$ \\
\hline $\begin{array}{l}\text { Szabadságjogok védelmének egyenlősége } \\
\text { (társadalmi csoportok között) }\end{array}$ & 0,89 & 0,72 & $72 \%$ & $-17 \%$ \\
\hline $\begin{array}{l}\text { A tényleges politikai hozzáférés egyenlő- } \\
\text { sége (társadalmi csoportok között) }\end{array}$ & 0,83 & 0,76 & $76 \%$ & $-7 \%$ \\
\hline Erőforrások egyenlő eloszlása & 0,79 & 0,67 & $67 \%$ & $-12 \%$ \\
\hline$\sum=$ Egalitarian democracy index & 0,70 & 0,40 & $40 \%$ & $-30 \%$ \\
\hline
\end{tabular}




\section{Economist Intelligence Unit Democracy Index (EIU)}

Az angol EIU - amely 2006 óta adja ki a világ 167 országára kiterjedő jelentéseit - hangsúlyozza, hogy az FH által összemosott „szabadság” és „demokrácia" terminusai korántsem szinonimái egymásnak, és a demokrácia fogalmának tágabb vizsgálata szükséges. A demokrácia szúken értelmezett megközelítésével dolgozó $F H$ felfogásával szemben az EIU azt vallja, hogy a "politikai jogokra és polgári szabadságjogokra korlátozódó mérések nem elég tágasak", hiszen „nem, vagy nem kielégítő mértékben tartalmazzák a demokrácia minőségét meghatározó jellegzetességeket". Az EIU módszertanában az igazi innovációt a (demokratikus) politikai kultúra és a politikai részvétel hangsúlyos volta jelenti. Az előbbi azért fontos, mivel a demokrácia több mint intézmények összessége, és a demokratikus politikai kultúra elengedhetetlen a legitimációhoz, hiszen a "passzív és apatikus, behódoló és alattvalói attitüddel bíró állampolgárság nem összeegyeztethető a demokráciával", amelyben a mindenkori vesztes pártok és támogatóik elfogadják a szavazás eredményét és a hatalom békés átadásának mechanizmusait. Ugyanennek a jelenségnek a másik oldala a tényleges politikai részvétel vizsgálata, amelyet az EIU szerint túlságosan leszúkít, ha csupán a kormányzatokra, mint társadalmi konstrukciókra koncentrálunk, hiszen „az egészséges demokráciák igénylik az állampolgárok közélettel kapcsolatos aktív, szabadon választott részvételi formáit". A demokráciák akkor "gyarapodnak, ha az állampolgárok részt vesznek a közéleti vitákban, képviselőket választanak és pártokhoz csatlakoznak", míg „széles, fenntartható részvétel nélkül a demokráciák elszáradnak és szúk, választott csoportok kiváltságaivá válnak". ${ }^{9}$ Összességében tehát az EIU nem csupán több dimenziót vizsgál, hanem a "free and fair" követelményt is mélyebben értelmezi, és kiemelten vizsgálja a demokrácia "szoftver jellegü” aspektusait.

A módszertant tekintve az EIU következetesen ugyanazt a 60 indikátort (kérdést) vizsgálja, mindegyik esetében két vagy három lehetőség közül kell választania a kutatóknak, amelyek közül néhányat survey felvételek vagy más elérhető statisztikák alapján kell a megadott sávokba besorolniuk, ám többségben vannak azok a kérdések, amelyeket a szakértőknek kell értékelniük. Ezen pontszámok összeadásából, illetve az összegeknek egy 0-10-es skálára (10 a legjobb) történő konvertálása során jön létre az öt kategória értékelése, majd az öt pontszám átlagából a végső demokráciaindex, amelyhez egy rezsimtipológia is tartozik (12. táblázat). Jól látható, hogy a szûkebb és statikusabb megközelítések helyett az EIU a demokráciák múködésére és fenntarthatóságára helyezi a hangsúlyt, így a formális kritériumok helyett a tényleges jellemzők kerülnek a fókuszba. A „teljes értékű demokrácia” így bizonyos értelemben robosztusabb és ellenállóbb, mint az eddig megszokott „liberális demokrácia” terminusa, míg a "hibás demokrácia” (flawed democracy) egy kisebb-nagyobb mértékben - illetve a mozgás irányától függően még vagy már 
- üresebb demokratikus épületnek (homlokzatnak) tekinthető, ahol a stabil, fenntartható és múködőképes demokráciához a valódi, mélyebb állampolgári részvétel aspektusai is szükségesek lennének. Míg az utóbbi kategória a „választási demokráciák" többé vagy kevésbé demokratikus formáival feleltethető meg, addig a "hibrid rezsimek" már a versengő autoriter és a választási autokráciák világát jelentik.

12. táblázat. Az Economist Intelligence Unit rezsimtípusai

\begin{tabular}{lll}
\hline Pontszám & Elnevezés & \multicolumn{1}{c}{ Definíció } \\
\hline $0-3,99$ & $\begin{array}{l}\text { Autoriter } \\
\text { rezsimek }\end{array}$ & $\begin{array}{l}\text { A politikai pluralizmus teljes hiánya vagy súlyos korláto- } \\
\text { zottsága jellemzi, a legtöbb ilyen ország nyílt diktatúra. A } \\
\text { demokrácia néhány formális intézménye létezhet, de kevés } \\
\text { valódi tartalommal; a választások (ha egyáltalán vannak) } \\
\end{array}$ \\
& & $\begin{array}{l}\text { se nem tisztességesek, se nem szabadok; a polgári szabad- } \\
\text { ságjogok súlyos megsértése, a politikai nyilvánosság és a } \\
\text { független igazságszolgáltatás hiánya, vagy részleges volta } \\
\end{array}$ \\
& jellemzi.
\end{tabular}

4-5,99 Hibrid rezsimek A választások az érdemi rendellenességek miatt többnyire se nem szabadok, se nem tisztességesek. A kormányzati nyomásgyakorlás mind az ellenzéki pártokra, mind jelöltjeikre nézve rendszeres. A "hibás demokráciákhoz” képest még súlyosabb hiányosságok tapasztalhatóak a kormányzat (demokratikus) múködése, a politikai részvétel és a politikai kultúra terén. A korrupció széleskörü, miközben a jogállam és a civil társadalom gyenge. Tipikus az újságírók zaklatása (nyomásgyakorlás) és az igazságszolgáltatás függő helyzete.

\begin{tabular}{|c|c|c|}
\hline $6-7,99$ & $\begin{array}{l}\text { Hibás } \\
\text { demokrácia }\end{array}$ & $\begin{array}{l}\text { A tisztességes és szabad választások mellett, még ha } \\
\text { problémák elő is fordulnak (mint például médiaszabadság } \\
\text { megsértése), tiszteletben tartják az alapvető polgári sza- } \\
\text { badságjogokat. Azonban a demokrácia más aspektusai te- } \\
\text { kintetében jelentős hiányosságok tapasztalhatóak, különös } \\
\text { tekintettel a kormányzat (demokratikus) múködése, a politikai } \\
\text { részvétel és a politikai kultúra területeire. A merkeli koncep- } \\
\text { ció defektusos demokráciájával feleltethető meg. }\end{array}$ \\
\hline
\end{tabular}

\begin{tabular}{|c|c|c|}
\hline$\overline{8-10}$ & $\begin{array}{l}\text { Teljes értékuu } \\
\text { demokrácia }\end{array}$ & $\begin{array}{l}\text { Azok az országok, amelyek nem csupán az alapvető politi- } \\
\text { kai jogokat és polgári szabadságjogokat tartják tiszteletben, } \\
\text { hanem a demokratikus politikai kultúra attribútumával is } \\
\text { rendelkeznek. A kormányzat (demokratikus) múködése kielé- } \\
\text { gítő, a nyilvánosság független és sokszínú, létezik a fékek } \\
\text { és ellensúlyok hatékony rendszere, ahogyan az igazság- } \\
\text { szolgáltatás is autonóm, amelynek döntéseit végrehajtják. } \\
\text { Csupán korlátozott hiányosságok figyelhetőek meg a de- } \\
\text { mokráciák múködése kapcsán. }\end{array}$ \\
\hline
\end{tabular}


Az EIU-jelentésekben Magyarország a „hibás demokráciák” kategóriájának felső harmadából annak alsó harmadára csúszott vissza, közelebb kerülve a „hibrid rezsimekhez", mint a "teljes értékű demokráciákhoz". A legutóbbi jelentésben az egy évvel korábbihoz képest a politikai kultúra kategória pontszáma jelentősen romlott, viszont ezt az országgyúlési választások relatíve magas részvételi aránya, illetve az emiatt megnövekvő politikai részvétel pontszáma ellensúlyozni tudta.

13. táblázat. Magyarország értékelése az EIU Demokráciaindexe alapján

\begin{tabular}{lcccc}
\hline Kategóriák & 2008 & 2018 & $\begin{array}{c}\text { 2018-as } \\
\text { arány }\end{array}$ & $\begin{array}{c}\text { Csökkenés } \\
\text { mértéke }\end{array}$ \\
\hline Választási eljárás és pluralizmus & 9,58 & 8,75 & $88 \%$ & $-8 \%$ \\
\hline Kormányzat (demokratikus) múködése & 6,07 & 6,07 & $61 \%$ & 0 \\
\hline Politikai részvétel & 5,56 & 5,00 & $50 \%$ & $-6 \%$ \\
\hline Politikai kultúra & 6,88 & 6,25 & $63 \%$ & $-6 \%$ \\
\hline Polgári szabadságjogok & 9,12 & 7,06 & $71 \%$ & $-21 \%$ \\
\hline Demokrácia-pontszám & 7,44 & 6,63 & $66 \%$ & $-8 \%$ \\
\hline
\end{tabular}

\section{Bertelsmann Transformation Index (BTI)}

A német Bertelsmann Stiftung a fejlődő és az átalakuló országok komplex vizsgálatának és nyomon követésének céljával szintén 2006 óta (kétévente) közli a Transformation Index két összetevőjének, a Status Index (SI) és a Governance Index (GI) pontszámait és a hozzájuk tartozó jelentéseket. A mögöttes demokráciakoncepció Wolfgang Merkel „beágyazott demokrácia” modelljével feleltethető meg (Merkel, 2004), amelyben a választási rendszer és a vertikális elszámoltathatóság nem csupán a polgári és a politikai szabadságjogok, a horizontális elszámoltathatóság vagy a kormányzásra való tényleges képesség dimenzióiba, hanem a civil társadalom egészébe és a szocioökonómiai kontextusba is beágyazott. A dahli modellen túlmutató megközelítés ennek megfelelően a jogállamisággal és szociális piacgazdasággal ötvözött demokrácia minőségét (a politikai és a gazdasági átalakulás - SI) és a jó kormányzást (GI) vizsgálja, összesen 17 kritérium 52 indikátorának segítségével.

A politikai átalakulás a képviselet minőségét a demokratikus konszolidáció vizsgálatának érdekében kiterjeszti a demokratikus intézmények stabilitásának valamint a politikai és társadalmi integráció különféle dimenzióinak vizsgálatára. A gazdasági átalakulás nem csupán a szúken értelmezett gazdasági teljesítmény szempontját, hanem a társadalmi igazságosság, a szociális biztonság, az esélyegyenlóség és a fenntarthatóság dimenzióit is bevonja egy ország gazdasági 
berendezkedésének értékelésébe. A jó kormányzást vizsgáló GI pedig a kormányzás és a közpolitikai döntéshozatal folyamatát és minőségét vizsgálja, beleértve például az elitek és a társadalom szintjén jelen lévő konszenzus mértékét is. Jelentős innováció tehát az eddigiekhez képest, hogy a komplex megközelítésbe a nemzetközi trendekhez hasonlóan (WEF, SGI) bekerültek a good governance és a fenntarthatóság dimenziói is. Utóbbiak többek között a civil társadalom és a nagypolitika között elterülő köztes politika világát vizsgálják - éppen azt, amelyben Magyarország nagyon jelentősen visszacsúszott: a vizsgált 129 országból a GI esetében 2008-ban még a 17., míg 2018-ban már csak a 79. helyezést érte el. Fontos jelezni, hogy a 2018-as évszám a jelentés megjelenésének évét jelzi, de a kemény adatokat nem számítva a pontszámok alapvetően a 2017-es év elejének állapotára vonatkoznak. ${ }^{10}$

A vizsgált területeket egy egységes, 1-10 pontos skálán (10 a legjobb) ${ }^{11}$ értékelik, amely kapcsán egy fél pont deficitnél valójában komolyabb üzenetértéke van egy esetleges 9,5 pontnak. Az összesített pontszámhoz kapcsolódik egy rezsimtipológia is:

- 1-3,99 Keményoonalas autokrácia: a demokratizációs trendek teljes hiánya.

-4-4,99 Moderált autokrácia: csak nyomokban vannak jelen bizonyos mértékủ alkotmányos és politikai részvételi minimum sztenderdek.

- 5-5,99 Súlyosan sérült demokrácia: a jogállamiság súlyos hiányosságai, az ellenzék korlátozott lehetôségei és választási manipulációk jellemzik.

- 6-7,99 Defektusos demokrácia: a relatíve szabad választások ellenére a politikai jogok és polgári szabadságjogok, illetve a valódi hatalommegosztás nem elégséges mértékben biztosított. Bár hosszú éveken át stabilak maradhatnak ezek az országok, mindazonáltal hajlamosak a politikai krízisek megélésére is.

- 8-10 Konszolidálódó demokrácia: jelentős a demokrácia elfogadottsága és kiterjedtek a hozzá kapcsolódó valódi struktúrák mind a képviselet minősége, mind a politikai kultúra terén - azaz a demokrácia társadalmi „lehorgonyozottsága" és beágyazottsága a jellemző.

A módszertan kifejezetten jelzi, hogy néhány (7) alkategóriának együttesen és mindegyiknek legalább egy minimális szinten (3-6 pontos küszöböknek megfelelve) kell teljesülnie bármilyen demokrácia-besoroláshoz. A küszöbértékek és a hazai pontszámok a "szabad és tisztességes választások" (6 vs. 7), a „hatalommegosztás" (4 vs. 5), illetve a „szólásszabadság” (4 vs. 6) alkategóriáiban kerültek leginkább közel egymáshoz 2017 elejére. Magyarország a BTI értékelésében a 2000-es évek második felében egy demokratikusan konszolidálódó, a szociális piacgazdaság tekintetében alapvetően fejlett, valamint kielégítő governance teljesítménnyel rendelkező ország volt, amely az elmúlt évtized de-demokratizációs folyamata nyomán a hibridizálódást látványosan jelző „defektusos demokrácia” kategóriájába került, összefüggésben a gazda- 
sági átalakulás és a governance minőségének súlyos mértékủ leromlásával. ${ }^{12}$ Ugyancsak megemlítendő, hogy eközben több (akár a rezsimbesoroláskor kiemelten kezelt) alkategória (lásd 15. táblázat) terén is 50\% környékére, vagy az alá zuhantak a pontszámok (vö. metafeltétel).

14. táblázat. Magyarország értékelése a Bertelsmann Transformation Index alapján

\begin{tabular}{lcc}
\hline Politikai átalakulás (demokrácia) & $\mathbf{2 0 0 8}$ & $\mathbf{2 0 1 8}$ \\
\hline Államiság & 9,35 & $\mathbf{7 , 1 5}$ \\
\hline Politikai részvétel & 10 & 9,3 \\
\hline Jogállamiságolidálódó & 10 & 7,5 \\
\hline Demokratikus intézmények stabilitása & $\begin{array}{c}\text { defektusos } \\
\text { demokrácia }\end{array}$ \\
\hline Politikai és társadalmi integráció & 9,25 & 6 \\
\hline
\end{tabular}

\begin{tabular}{lcc}
\hline Gazdasági átalakulás & 9 & 7,71 \\
\hline & fejlett & múködóképes \\
\hline Szocioökonómiai fejlettség mértéke & 10 & 8 \\
\hline A piac (verseny) múködése & 10 & 8,5 \\
\hline Valuta és árfolyam stabilitása & 8,5 & 7,5 \\
\hline Magántulajdon védelme & 10 & 8,5 \\
\hline Jóléti rezsim & 9 & 7,5 \\
\hline $\begin{array}{l}\text { Gazdasági teljesítmény } \\
\text { Fenntarthatóság }\end{array}$ & 7 & 8 \\
\hline & 8,5 & 6 \\
\hline Governance Index & 6,7 & \\
\hline & jó & közepes \\
\hline $\begin{array}{l}\text { Döntéshozatal strukturális és társadalmi } \\
\text { körülményei, * fordított skála }\end{array}$ & 1,6 & 1,9 \\
\hline Kitüzött célok koherenciája és megvalósitása & 8,33 & 5,66 \\
\hline Eröforrások hatékony kihasználása & 7,33 & 5,33 \\
\hline $\begin{array}{l}\text { Elitek és a társadalom szintjén jelen lévö } \\
\text { konszenzus mértéke }\end{array}$ & 8 & 5 \\
\hline Nemzetközi együttmúködés & 9,33 & 5,66 \\
\hline
\end{tabular}


15. táblázat. Magyarország értékelése a BTI State of Political Transformation alapján

\begin{tabular}{|c|c|c|c|c|}
\hline Kategóriák & 2008 & 2018 & $\begin{array}{l}\text { 2018-as } \\
\text { arány }\end{array}$ & $\begin{array}{l}\text { Csökkenés } \\
\text { mértéke }\end{array}$ \\
\hline Államiság & 10 & 9,3 & $92 \%$ & $-8 \%$ \\
\hline Erőszakmonopólium kiterjedtsége & 10 & 10 & $100 \%$ & 0 \\
\hline Állami hatalom elfogadottsága & 10 & 9 & $89 \%$ & $-11 \%$ \\
\hline $\begin{array}{l}\text { Vallási dogmák befolyása nélküli törvényes } \\
\text { rend és intézmények }\end{array}$ & 10 & 8 & $78 \%$ & $-22 \%$ \\
\hline Alapvető közigazgatás & 10 & 10 & $100 \%$ & 0 \\
\hline Politikai részvétel & 10 & 7,5 & $72 \%$ & $-28 \%$ \\
\hline Szabad és tisztességes választások & 10 & 7 & $67 \%$ & $-33 \%$ \\
\hline Demokratikus kormányzás lehetősége & 10 & 10 & $100 \%$ & 0 \\
\hline Egyesülési és gyülekezési jogok & 10 & 7 & $67 \%$ & $-33 \%$ \\
\hline Szólásszabadság & 10 & 6 & $56 \%$ & $-44 \%$ \\
\hline Jogállamiság & 9,25 & 6 & $56 \%$ & $-36 \%$ \\
\hline Hatalommegosztás & 10 & 5 & $44 \%$ & $-56 \%$ \\
\hline Független bírói hatalom & 9 & 6 & $56 \%$ & $-33 \%$ \\
\hline Hivatali hatalommal való visszaélés & 8 & 6 & $56 \%$ & $-22 \%$ \\
\hline Polgári szabadságjogok & 10 & 7 & $67 \%$ & $-33 \%$ \\
\hline Demokratikus intézmények stabilitása & 9 & 6,5 & $61 \%$ & $-28 \%$ \\
\hline Demokratikus intézmények teljesítménye & 8 & 6 & $56 \%$ & $-22 \%$ \\
\hline $\begin{array}{l}\text { Demokratikus intézmények elfogadottsága } \\
\text { a releváns szereplők körében }\end{array}$ & 10 & 7 & $67 \%$ & $-33 \%$ \\
\hline Politikai és társadalmi integráció & 8,5 & 6,5 & $61 \%$ & $-22 \%$ \\
\hline Pártrendszer beágyazottsága és stabilitása & 9 & 7 & $67 \%$ & $-22 \%$ \\
\hline $\begin{array}{l}\text { Társadalom és a politikai rendszer } \\
\text { közötti közvetítő közegek (egyesületek, } \\
\text { érdekcsoportok stb.) }\end{array}$ & 8 & 6 & $56 \%$ & $-22 \%$ \\
\hline Demokrácia támogatottsága & 9 & 7 & $67 \%$ & $-22 \%$ \\
\hline Társadalmi tőke, aktivitás, bizalom & 8 & 6 & $56 \%$ & $-20 \%$ \\
\hline Demokráciapontszám & 9,35 & 7,15 & $68 \%$ & $-24 \%$ \\
\hline
\end{tabular}




\section{Összefoglaló táblázatok}

A Magyarország mellett Románia és Szlovákia rangsorváltozásait jelző 16. táblázat után szeretném bemutatni az eddig tárgyalt demokráciaindexek összesített (17.) táblázatát. Itt a különféle demokráciaindexeknél a harmadik oszlopban azt jelzem vázlatosan, hogy milyen dimenziókkal dolgoznak: fentről lefelé haladva igyekszem jelezni, hogy melyek azok a legfontosabb pluszdimenziók (+), amelyek bekerülnek az egyes megközelítésekbe, illetve, hogy milyen súlylyal esnek latba: $(+) /+/++/+++$. A sorrend tehát tekinthető egyfajta „erősorrendnek" is: minél lentebb kapott helyet egy index, annál több dimenzióval dolgozik, illetve azokat mélyebben is vizsgálja, azaz egyre kiterjedtebbé válik a társadalmi-gazdasági fókusz a szúken értelmezett politikai helyett.

16. táblázat. Magyarország, Szlovákia és Románia helyezései négy intézet rangsorában

\begin{tabular}{llll}
\hline Ország/Index & $\mathbf{2 0 0 8 / 2 0 0 9}$ & $\mathbf{2 0 1 8 / 2 0 1 9}$ \\
\hline FH FiW & & \\
\hline & Magyarország & 37 & 86 \\
\cline { 2 - 4 } & Szlovákia & 45 & 49 \\
\cline { 2 - 4 } & Románia & 64 & 66 \\
\hline
\end{tabular}

V-Dem Választási demokrácia

\begin{tabular}{llll}
\hline Magyarország & 38 & 93 \\
\cline { 2 - 4 } Szlovákia & 30 & 29 \\
\cline { 2 - 4 } Románia & 63 & 69 \\
\hline
\end{tabular}

EIU Democracy Index

\begin{tabular}{llll}
\hline Magyarország & 40 & 57 \\
\cline { 2 - 4 } Szlovákia & 44 & 44 \\
\cline { 2 - 4 } Románia & 50 & 66 \\
\hline
\end{tabular}

BTI Democracy Status

\begin{tabular}{lcl} 
Magyarország & 5 & 32 \\
\hline Szlovákia & 10 & 10 \\
\hline Románia & 18 & 17
\end{tabular}




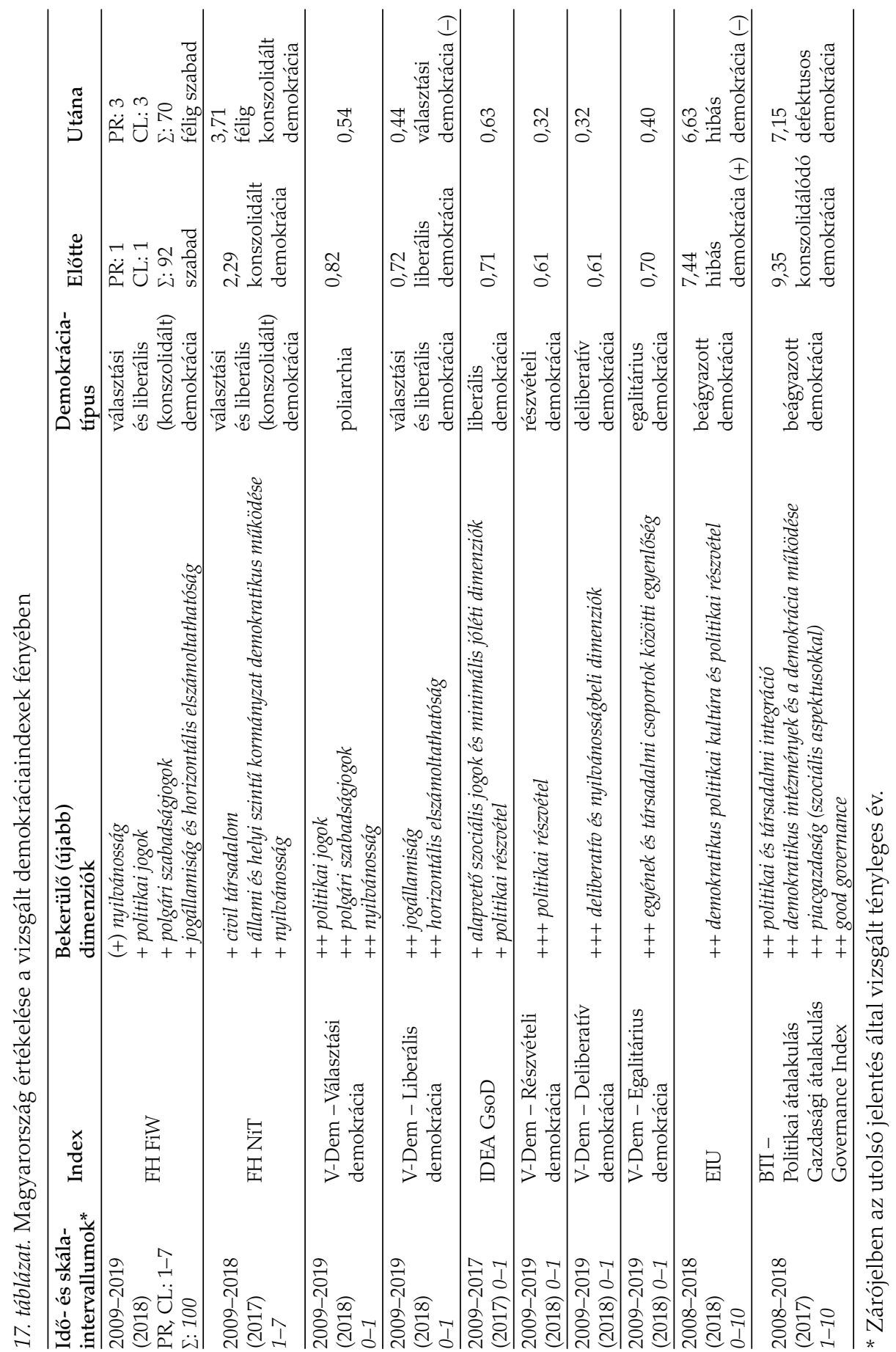




\section{AZ INDEXEK KERESZTMETSZETEI ÉS MAGYARORSZÁG ÉRTÉKELÉSE}

Végezetül szeretném bemutatni a de-demokratizáció folyamata nyomán leginkább sérült területeket és a hozzájuk kapcsolódó keresztmetszeti táblázatokat, amelyek a politikai versengés minimálisra szorításának különféle dimenzióit takarják, és így talán hasznosak lehetnek a kurrens rezsimvita számára is. A releváns demokráciaindexek középszintű komponenseit és indikátorait megvizsgálva alapvetően öt súlyosan sérült területet különböztettem meg: (1) nyilvánosság; (2) a kormányzat demokratikus múködése; (3) részvétel; (4) választások; (5) jogállam, alkotmányos kontroll és horizontális elszámoltathatóság.

18. táblázat. Magyarország a nyilvánossághoz köthető értékelésekben

\begin{tabular}{|c|c|c|c|c|c|c|}
\hline Kategóriák & Index & $\begin{array}{l}\text { Jelentések } \\
\text { évszámai }\end{array}$ & Előtte & Utána & $\begin{array}{l}\text { Arány } \\
\text { utána }\end{array}$ & $\begin{array}{l}\text { Csökkenés } \\
\text { mértéke }\end{array}$ \\
\hline $\begin{array}{l}\text { Független } \\
\text { média }\end{array}$ & FH NiT & 2009-2018 & 2,50 & 4,50 & $42 \%$ & $-33 \%$ \\
\hline \multirow{2}{*}{$\begin{array}{l}\text { Nyomtatott } \\
\text { sajtó } \\
\text { szabadsága }\end{array}$} & $\begin{array}{l}\text { FH Freedom } \\
\text { of the Press }\end{array}$ & 2009-2017 & $\begin{array}{c}21 \\
\text { szabad }\end{array}$ & $\begin{array}{c}44 \\
\text { félig szabad }\end{array}$ & $56 \%$ & $-23 \%$ \\
\hline & $\begin{array}{l}\text { Riporterek } \\
\text { határok nélkül }\end{array}$ & 2009-2018 & $\begin{array}{l}5,50 \\
\text { jó }\end{array}$ & $\begin{array}{c}\text { 30,44 } \\
\text { problémás }\end{array}$ & & \\
\hline $\begin{array}{l}\text { Internet } \\
\text { szabadsága }\end{array}$ & $\begin{array}{l}\text { FH Freedom } \\
\text { of the Net }\end{array}$ & $2012-2018$ & $\begin{array}{c}19 \\
\text { szabad }\end{array}$ & $\begin{array}{c}29 \\
\text { szabad }\end{array}$ & $71 \%$ & $-10 \%$ \\
\hline $\begin{array}{l}\text { Média- } \\
\text { szabadság } \\
\text { státusza }\end{array}$ & EIU & 2017 & n. a. & $\begin{array}{c}\text { nagyrészt } \\
\text { nem } \\
\text { szabad }\end{array}$ & $\begin{array}{c}55 \% \\
(6 / 11)\end{array}$ & n. a. \\
\hline $\begin{array}{l}\text { Szólás- } \\
\text { szabadság }\end{array}$ & $\begin{array}{l}\text { FH FiW } \\
\text { BTI } \\
\text { V-Dem }\end{array}$ & $\begin{array}{l}2009-2019 \\
2008-2018 \\
2009-2019 \\
\end{array}$ & $\begin{array}{c}16 \\
10 \\
0,96 \\
\end{array}$ & $\begin{array}{c}10 \\
6 \\
0,68 \\
\end{array}$ & $\begin{array}{l}63 \% \\
56 \% \\
68 \% \\
\end{array}$ & $\begin{array}{l}-38 \% \\
-37 \% \\
-28 \% \\
\end{array}$ \\
\hline $\begin{array}{l}\text { Média- } \\
\text { cenzúra } \\
\text { (közvetett is) }\end{array}$ & V-Dem & 2009-2019 & 3,58 & 2,07 & $52 \%$ & $-38 \%$ \\
\hline $\begin{array}{l}\text { Kritikus } \\
\text { média } \\
\text { jelenléte }\end{array}$ & V-Dem & 2009-2019 & 2,60 & 1,70 & $57 \%$ & $-30 \%$ \\
\hline $\begin{array}{l}\text { Alternatív } \\
\text { információ- } \\
\text { források }\end{array}$ & V-Dem & 2009-2019 & 0,86 & 0,53 & $53 \%$ & $-33 \%$ \\
\hline
\end{tabular}


19. táblázat. Magyarország a kormányzat demokratikus müködéséhez köthető értékelésekben

\begin{tabular}{|c|c|c|c|c|c|c|}
\hline Kategóriák & Index & $\begin{array}{l}\text { Jelentések } \\
\text { évszámai }\end{array}$ & Előtte & Utána & $\begin{array}{l}\text { Arány } \\
\text { utána }\end{array}$ & $\begin{array}{l}\text { Csökkenés } \\
\text { mértéke }\end{array}$ \\
\hline $\begin{array}{l}\text { Kormányzás demokra- } \\
\text { tikus minősége }\end{array}$ & FH NiT & 2009-2018 & 2,50 & 4,50 & $42 \%$ & $-33 \%$ \\
\hline Állami korrupció & FH NiT & $2009-2018$ & 3,00 & 4,75 & $38 \%$ & $-29 \%$ \\
\hline Politikai korrupció & V-Dem & 2009-2019 & 0,32 & 0,47 & $53 \%$ & $-15 \%$ \\
\hline $\begin{array}{l}\text { Hivatali hatalommal } \\
\text { való visszaélés }\end{array}$ & BTI & 2008-2018 & 8 & 6 & $56 \%$ & $-22 \%$ \\
\hline $\begin{array}{l}\text { Kiszámítható és tisz- } \\
\text { tességes közigazgatás }\end{array}$ & $\begin{array}{l}\text { IDEA } \\
\text { GSoD }\end{array}$ & 2009-2017 & 0,72 & 0,59 & $59 \%$ & $-13 \%$ \\
\hline $\begin{array}{l}\text { Demokratikus intéz- } \\
\text { mények teljesítménye }\end{array}$ & BTI & 2008-2018 & 8 & 6 & $56 \%$ & $-22 \%$ \\
\hline $\begin{array}{l}\text { Demokratikus intéz- } \\
\text { mények elfogadottsá- } \\
\text { ga a releváns } \\
\text { szereplők körében }\end{array}$ & BTI & 2008-2018 & 10 & 7 & $67 \%$ & $-33 \%$ \\
\hline $\begin{array}{l}\text { Döntések átlátható } \\
\text { és ésszerü igazolása, } \\
\text { * skála: } 0-3\end{array}$ & V-Dem & 2009-2019 & 1,87 & 1,25 & $42 \%$ & $-20 \%$ \\
\hline $\begin{array}{l}\text { Ellenvélemények } \\
\text { tisztelete, }{ }^{*} 0-5\end{array}$ & V-Dem & 2009-2019 & 2,77 & 1,64 & $33 \%$ & $-22 \%$ \\
\hline
\end{tabular}

20. táblázat. Magyarország a politikai részvételhez köthető értékelésekben

\begin{tabular}{|c|c|c|c|c|c|c|}
\hline Kategóriák & Index & $\begin{array}{l}\text { Jelentések } \\
\text { évszámai }\end{array}$ & Előtte & Utána & $\begin{array}{l}\text { Arány } \\
\text { utána }\end{array}$ & $\begin{array}{l}\text { Csökkenés } \\
\text { mértéke }\end{array}$ \\
\hline \multirow{2}{*}{ Civil társadalom } & FH NiT & 2009-2018 & 1,75 & 3,00 & $67 \%$ & $-21 \%$ \\
\hline & V-Dem & 2009-2019 & 0,81 & 0,49 & $49 \%$ & $-32 \%$ \\
\hline $\begin{array}{l}\text { Civil szervezetek } \\
\text { elnyomása, }{ }^{*} \text { skála: 0-4 }\end{array}$ & V-Dem & 2009-2019 & 3,60 & 2,23 & $56 \%$ & $-34 \%$ \\
\hline Politikai részvétel & EIU & 2008-2018 & 5,56 & 5,00 & $50 \%$ & $-6 \%$ \\
\hline $\begin{array}{l}\text { Egyesülési és } \\
\text { gyülekezési jogok }\end{array}$ & BTI & 2008-2018 & 10 & 7 & $67 \%$ & $-33 \%$ \\
\hline $\begin{array}{l}\text { Politikai és társadalmi } \\
\text { integráció }\end{array}$ & BTI & 2008-2018 & 8,5 & 6,5 & $61 \%$ & $-22 \%$ \\
\hline \multicolumn{3}{|c|}{ Pártrendszer beágyazottsága és stabilitása } & 9 & 7 & $67 \%$ & $-22 \%$ \\
\hline \multicolumn{3}{|c|}{$\begin{array}{l}\text { Társadalom és a politikai rendszer közötti } \\
\text { közvetítő közegek }\end{array}$} & 8 & 6 & $56 \%$ & $-22 \%$ \\
\hline \multicolumn{3}{|c|}{ Demokrácia támogatottsága } & 9 & 7 & $67 \%$ & $-22 \%$ \\
\hline \multicolumn{3}{|c|}{ Társadalmi tőke, aktivitás, bizalom } & 8 & 6 & $56 \%$ & $-22 \%$ \\
\hline $\begin{array}{l}\text { Társadalmi vita és valódi } \\
\text { bevonás a döntéshozatal } \\
\text { során, }{ }^{*} 0-5\end{array}$ & V-Dem & 2009-2019 & 2,70 & 2,17 & $43 \%$ & $-11 \%$ \\
\hline
\end{tabular}


21. táblázat. Magyarország a választásokhoz köthető értékelésekben

\begin{tabular}{|c|c|c|c|c|c|c|}
\hline Kategóriák & Index & $\begin{array}{l}\text { Jelentések } \\
\text { évszámai }\end{array}$ & Előtte & Utána & $\begin{array}{l}\text { Arány } \\
\text { utána }\end{array}$ & $\begin{array}{l}\text { Csökkenés } \\
\text { mértéke }\end{array}$ \\
\hline \multirow{2}{*}{ Választási eljárás } & FH NiT & 2009-2018 & 1,75 & 3,25 & $63 \%$ & $-25 \%$ \\
\hline & FH FiW & 2009-2019 & 12 & 9 & $75 \%$ & $-25 \%$ \\
\hline \multirow[b]{2}{*}{ Tiszta választások } & IDEA & 2009-2017 & 0,84 & 0,71 & $71 \%$ & $-13 \%$ \\
\hline & $\begin{array}{l}\text { GSoD } \\
\text { V-Dem }\end{array}$ & 2009-2019 & 0,93 & 0,71 & $71 \%$ & $-22 \%$ \\
\hline $\begin{array}{l}\text { Választási folyamat és } \\
\text { pluralizmus }\end{array}$ & EIU & 2008-2018 & 9,58 & 8,75 & $88 \%$ & $-8 \%$ \\
\hline $\begin{array}{l}\text { Szabad és tisztességes } \\
\text { választások }\end{array}$ & BTI & 2008-2018 & 10 & 7 & $67 \%$ & $-33 \%$ \\
\hline
\end{tabular}

22. táblázat. Magyarország a jogállam, alkotmányos kontroll és horizontális elszámoltathatóság dimenzióihoz köthető értékelésekben

\begin{tabular}{|c|c|c|c|c|c|c|}
\hline Kategóriák & Index & $\begin{array}{l}\text { Jelentések } \\
\text { évszámai }\end{array}$ & Előtte & Utána & $\begin{array}{l}\text { Arány } \\
\text { utána }\end{array}$ & $\begin{array}{l}\text { Csökkenés } \\
\text { mértéke }\end{array}$ \\
\hline $\begin{array}{l}\text { Igazságszolgáltatás } \\
\text { intézményrendszere és } \\
\text { függetlensége }\end{array}$ & $\begin{array}{l}\text { FH NiT } \\
\text { IDEA } \\
\text { GSoD } \\
\text { BTI }\end{array}$ & $\begin{array}{l}2009-2018 \\
2009-2017 \\
2008-2018\end{array}$ & $\begin{array}{c}1,75 \\
0,68 \\
9\end{array}$ & $\begin{array}{c}3 \\
0,64 \\
6\end{array}$ & $\begin{array}{l}67 \% \\
64 \% \\
56 \%\end{array}$ & $\begin{array}{l}-21 \% \\
-4 \% \\
-33 \% \\
\end{array}$ \\
\hline $\begin{array}{l}\text { Törvényhozás, mint a } \\
\text { végrehajtás korlátja }\end{array}$ & $\begin{array}{l}\text { IDEA } \\
\text { GSoD } \\
\text { V-Dem }\end{array}$ & $\begin{array}{l}2009-2017 \\
2009-2019\end{array}$ & $\begin{array}{l}0,68 \\
0,88\end{array}$ & $\begin{array}{l}0,63 \\
0,63\end{array}$ & $\begin{array}{l}63 \% \\
63 \%\end{array}$ & $\begin{array}{l}-5 \% \\
-25 \% \\
\end{array}$ \\
\hline Hatalommegosztás & BTI & 2008-2018 & 10 & 5 & $44 \%$ & $-56 \%$ \\
\hline Polgári szabadságjogok & $\begin{array}{l}\text { FH FiW } \\
\text { IDEA } \\
\text { GSoD } \\
\text { EIU } \\
\text { BTI }\end{array}$ & $\begin{array}{l}2009-2019 \\
2009-2017 \\
2008-2018 \\
2008-2018\end{array}$ & $\begin{array}{c}55 \\
0,83 \\
9,12 \\
10\end{array}$ & $\begin{array}{c}43 \\
0,70 \\
7,06 \\
7\end{array}$ & $\begin{array}{l}72 \% \\
70 \% \\
71 \% \\
67 \%\end{array}$ & $\begin{array}{l}-20 \% \\
-13 \% \\
-21 \% \\
-33 \%\end{array}$ \\
\hline Jogállamiság & $\begin{array}{l}\text { V-Dem } \\
\text { BTI } \\
\text { FH FiW }\end{array}$ & $\begin{array}{l}2009-2019 \\
2008-2018 \\
2009-2019\end{array}$ & $\begin{array}{c}0,89 \\
9,25 \\
13\end{array}$ & $\begin{array}{c}0,73 \\
6 \\
10\end{array}$ & $\begin{array}{l}73 \% \\
56 \% \\
63 \% \\
\end{array}$ & $\begin{array}{l}-16 \% \\
-36 \% \\
-19 \%\end{array}$ \\
\hline
\end{tabular}

\section{KÖVETKEZTETÉSEK}

Az indexek keresztmetszetei (és a kapcsolódó jelentések) alapján egy olyan rezsim képe rajzolódik ki, amelyet egy súlyosan korlátozott politikai-közéleti nyilvánosság; egy mélyen korrupt, az állami hatalmat a saját érdekei érvényesítésére rutinszerüen felhasználó hatalom; egy felülről irányított, top-down jellegú antidemokratikus és valódi társadalmi részvétel nélküli politikai univerzum; a választások formális feltételeinek is jelentős sérülése; valamint a jogállami ke- 
retek súlyos eróziója jellemez (18-22. táblázatok). A hazai politikai berendezkedés ilyen mértékú és rendszerszintû sérülése esetén meglátásom szerint egyértelmü, hogy az Orbán-rezsim hegemón és autoriter természete nem egyeztethető össze a pluralista demokrácia (dahli) koncepciójával, amelyben nem csupán az egyes elemek (teljesülésének) átlaga kell(ene), hogy elérjen egy meghatározott szintet, hanem azok mindegyikének külön-külön is kielégítő mértékben kell(ene) jelen lennie. Schedler metaforájával élve a „demokratikus választás láncolata" megtört, nem csupán rendszerszinten tekinthető érdeminek a sérülés, hanem több láncszem kiesésével maga a láncolat is megszűnt létezni. A további rezsimbesorolást és a rezsimvitát nehezíti, hogy nem egy, hanem több, egymással is összefüggő ponton (elemben) lehet érdemi sérülést regisztrálni, így a demokratikus versengésnek a különféle szinteken történó szimultán és egymást erösitoó, rendszerszintú aláásása és kiüresitése a legfontosabb jellemzö.

Ez a tény - amelyet a 2018-as választások kapcsán már az EBESZ előzetes megállapításai és következtetései is kiemelnek ${ }^{13}$ - mindenképpen alátámasztja a Levitsky-Way szerzőpáros $(2002,2010)$ által bevezetett, az inkumbens és az ellenzék közötti szisztematikusan „egyenlőtlen játéktér” (uneven playing field) koncepciójának hazai érvényességét, különösen az erőforrásokhoz, a nyilvánossághoz és a korrekt jogalkalmazáshoz való hozzáférés tekintetében. Azaz az eredmények visszaigazolják a hazai rezsimvitában a hibrid vagy versengó autoriter megnevezéseket, sót - bár a verseny valódi mértékének megítélése meglehetôsen szubjektív müfaj (nem beszélve az általános információhiány problémájáról) ennél is súlyosabb következtetések is kiolvashatóak belölük. Még ennél is biztosabban állítható, hogy az elmúlt évtized súlyos de-demokratizációs folyamatai nyomán nem csupán a demokratikus látszatok mögötti tartalmi és múködésbeli demokráciaelemek üresedtek ki látványosan, hanem a demokratikus legitimitás begyưjtésére fenntartott formális homlokzat is omladozik, egyre inkább felfedve és erősítve pusztán díszletjellegét.

\section{JEGYZETEK}

1 Körösényi András kapcsán megemlítendő, hogy a plebiszciter vezérdemokrácia (PVD) koncepciójának hazai adaptálása és kifejlesztése nyomán demokratikus keretben (autoriter tartalom mellett) értelmezte a hazai berendezkedést: „a politikai rendszer azonban nem pusztán a versengő választások miatt demokratikus, hanem - mint fentebb már utaltam rá - minden bizonynyal átmegy Robert Dahl poliarchiatesztjén is: azaz a demokratikus uralom egy formájáról van szó” (Körösényi, 2015: 413-414.). Ugyanakkor felvetette „az új rezsimnek a hibrid rendszer paradigmában történő értelmezését" is (uo.). A későbbiekben viszont nem „köztes” vagy reziduális hibrid rezsimként, hanem önálló, sui generis rezsimtípusként értelmezi az Orbán-rezsimet: „a PVD cezarista politikai uralmat teremt, azaz formájában demokratikus, miközben tartalmában autoriter rendszer" (Körösényi, 2017: 9.), amelyben „a politika primátusa és az autoriter hata- 
lomgyakorlás 2010 és 2016 között kikezdte a procedurális demokrácia (a dahli poliarchia) kifinomult intézményrendszerét, de a versengő választások megmaradtak." (i. m. 25.). Összességében meghatározó maradt értelmezésében a rezsim demokratikus formája, amely szimbiózist alkot az autoriter tartalommal, így a PVD-ben a „demokrácia és autokrácia nem egymást kizáró, de nem is pusztán egymással összeférő, összeegyeztethető, hanem egymással szervesen, endogén módon összetartozó, összefonódó uralmi típusok" (i. m. 14.) A demokrácia/autokrácia dichotómia (vagy kontinuum) elutasításával és meghaladásával ezeknek a fogalmaknak és így a velük (külön-külön) lefedhető tartományoknak a tágításáról, azaz bizonyos szempontból egy „leértékelt" demokráciakoncepcióról beszélhetünk.

Csizmadia Ervin szerint egyfelől a hazai folyamatok tulajdonképpen az ország évszázados politikai hagyományaihoz tértek vissza, amelyben egy erős többségú, nehezen leváltható domináns politikai erő kormányoz egy számára előnyös (centrális) erőtérben, másfelől csupán a liberális demokrácia első komponensének sérüléséről, illetve annak korábbi konszolidálatlanságáról lehet beszélni. „Miért változott meg a korai demokráciafelfogás és miért jött létre a liberális demokrácia helyett illiberális? (...) De az is újdonság, hogy a magyar demokrácia elmúlt közel 30 évében egyáltalán bekövetkezik menedzserpárt-váltás.” „A magyar közéletben sikertelen marad a demokrácia liberálissá történő továbbfejlesztése" (kiemelések tőlem) (Csizmadia, 2017).

2 Jelen tanulmányban de-demokratizáció alatt az állam és polgárai közötti viszonyrendszerben a szúkebb, az egyenlőtlenebb, az önkényességtől kevésbé védett és a kölcsönösen kevésbé kötelező jellegú (aszimmetrikus) kapcsolat irányába történő elmozdulás folyamatát értem (Tilly, 2007: 14-15., 59.).

3 A hibrid rezsimek irodalmáról szóló áttekintéshez lásd például: Gyulai-Stein-Zalai (2016) vagy Tóth (2016).

4 A Polity IV esetében igyekeznek kemény adatokra támaszkodni, amelyek a megbízhatóság tekintetében hasznosak lehetnek, azonban a demokrácia rendkívül szúken értelmezett felfogására építve az érvényesség tekintetében már súlyos hiányosságok merülnek fel. A szúk megközelítés és a magas fokú absztrakció nyomán nagyon könnyen elérhető a maximális pontszám, ezek miatt ez a megközelítés nem alkalmas a finomabb distinkciókra, ezért kimarad a tanulmány további részéből.

5 https://freedomhouse.org/report/methodology-freedom-world-2019

6 Mivel itt a FiW-tôl eltérően nem lehet 0 pontot kiosztani, ezért az arányok számításakor az 1-7es skálán 4 pont lett a középérték.

7 https://www.idea.int/data-tools

8 https://www.v-dem.net/en/

9 https://www.economist.com/media/pdf/DEMOCRACY_INDEX_2007_v3.pdf

${ }^{10}$ https://www.bti-project.org/en/reports/country-reports/detail/itc/HUN/

${ }^{11}$ Mivel itt az FH NiT pontrendszeréhez hasonlóan szintén nem adható 0 pont, ezért az arányok számításakor az 1-10-es skálán 5,50 pont lett a középérték.

${ }^{12}$ Magyarország 2018-as jelentése: https://www.bti-project.org/en/reports/country-reports/detail/ itc/HUN/ 
${ }_{13}$ „Az április 8-i országgyúlési választásokat az állam és a kormánypártok anyagi forrásainak jelentős átfedése határozta meg, aláásva a jelöltek lehetőségét arra, hogy egyenlő feltételek mellett versengjenek". https://www.osce.org/hu/odihr/elections/hungary/377413?download=true

\section{IRODALOM}

Ágh Attila (2012): Demokráciakutatás a politikai és közpolitikai elemzés keresztútján: a demokráciák minősége és teljesítőképessége. Politikatudományi Szemle, 21 (2), 55-72.

Ágh, Attila (2015): De-Europeanization and de-Democratization trends in ECE: From the Potemkin democracy to the elected autocracy in Hungary. Journal of Comparative Politics, 8 (2), 4-26.

Ágh, Attila (2016): The Decline of Democracy in East-Central Europe. Hungary as the Worst-Case Scenario. Problems of Post-Communism, 63 (5-6), 277-287. https://doi.org/10.1080/10758216.2015. 1113383

Antal Attila (2019a): Orbán bárkája. Az autoriter állam és a kapitalizmus szövetsége. Progress könyvek, Kossuth Kiadó.

Antal Attila (2019b): A rendszer ellen. Mérce.hu, 2019. február 26. https://merce.hu/2019/02/26/ a-rendszer-ellen/

Böcskei Balázs (2019): Hogyan dönthető meg az orbáni hibrid rezsim? 24.hu, 2019. január 17.

Bozóki András-Hegedûs Dániel (2017): A kívülről korlátozott hibrid rendszer. Az Orbán-rezsim a rendszertipológia tükrében. Politikatudományi Szemle, 26 (2), 7-32

Bollen, Kenneth A-Pamela Paxton (2000): Subjective measures of liberal democracy. Comparative Political Studies, 33 (1), 58-86. https://doi.org/10.1177/0010414000033001003

Bush, Sarah S. (2017): The Politics of Rating Freedom: Ideological Affinity, Private Authority, and the Freedom in the World Ratings. Perspectives on Politics, 15 (3), 711-731. https://doi.org/10.1017/ s1537592717000925

Campbell, David F. (2008): The Basic Concept for the Democracy Ranking of the Quality of Democracy, Vienna: Democracy Ranking.

Collier, David-Steven Levitsky (1997). Democracy with Adjectives: Conceptual Innovation in Comparative Research. World Politics, 49 (3), 430-451. https://doi.org/10.1353/wp.1997.0009

Collier, David-Steven Levitsky (2009): Conceptual Hierarchies in Comparative Research: The Case of Democracy. In: Collier et al. (2009): Concepts and Method in the Social Science: The Tradition of Giovanni Sartori. London, Routledge, 269-288. https://doi.org/10.7202/039020ar

Coppedge, Michael-Jan Teorell-Svend-Erik Skaaning et al. (2011): Conceptualizing and Measuring Democracy: A New Approach. Perspectives on Politics, 9 (2), 247-267. https://doi.org/10.1017/ s1537592711000880

Csizmadia Ervin (2017): A demokrácia változatairól - normalitás vagy abnormalitás? I-II. rész. Mandiner.hu, 2017.12.05. https://mandiner.hu/cikk/20171204_csizmadia_ervin_normalitas_vagy_ abnormalitas_i https://mandiner.hu/cikk/20171205_csizmadia_ervin_a_demokracia_valtozatairol_ normalitas_vagy_abnormalitas_ii

Dahl, Robert A. (1971): Polyarchy. Participation and Opposition. Yale University Press.

Dahl, Robert A. (1998): On Democracy. Harrisonburg, Yale University Press. 
Dahl, Robert A. (2006): A Preface to a Democratic Theory. Chicago, The University of Chicago Press. Denk, Thomas (2012): How to measure polyarchy with Freedom House: A proposal for revision. Quality and Quantity, 47 (6), 3457-3471. https://doi.org/10.1007/s11135-012-9732-1

Diamond, Larry (1996): Is the Third Wave Over? Journal of Democracy, 7 (3). 20-37. https://doi. org/10.1353/jod.1996.0047

Diamond, Larry-Leonardo Morlino (2004): The Quality of Democracy. An Overview. Journal of Democracy, 15 (4), 20-31. https://doi.org/10.1353/jod.2004.0060

Diamond, Larry-Emily C. Green-William Gallery (2016): Measuring democracy. In: Diamond, Larry: In Search of Democracy. Routledge. https://doi.org/10.4324/9781315685175-3

Filippov Gábor: A hibrid ellenforradalom kora. 24.hu, 2018. július 31.

Geissel, Brigitte-Marianne Kneuer-Hans-Joachim Lauth (2016): Measuring the quality of democracy: Introduction. International Political Science Review, 37 (5), 571-579. https://doi.org/10.1177/ 0192512116669141

Gyulai Attila-Stein-Zalai Juliane (2016): Hibrid rezsimek és a szürke zóna: új válaszok a politikai rezsimek rendszertanának örök kérdéseire. Metszetek, 2016 (2), 42-59. https://doi.org/10.18392/ metsz/2016/2/9

Gyulai Attila (2017): Magyarország a szürke zónában? A magyar politikai rendszer hosszú hibridizációja. In: Boda Zsolt-Szabó Andrea (szerk.): Trendek a magyar politikában - 2. A Fidesz és a többiek: pártok, mozgalmak, politikák. Budapest, Napvilág-MTA TK, 15-42.

Högström, John (2013): Classification and Rating of Democracy: A Comparison. Taiwan Journal of Democracy, 9 (2), 33-54.

Jakab, András-Lőrincz Viktor (2016): A jogrendszerek mérése indexek segítségével. In: Jakab András-Gajduschek György (szerk.): A magyar jogrendszer állapota. Budapest, MTA TK, 869-895.

Kornai János (2015): Hungary's U-Turn: Retreating from Democracy. Journal of Democracy, 26 (3), 34-48.

Körösényi András (2015): A magyar demokrácia három szakasza és az Orbán-rezsim. In: (szerk.) Körösényi András: A magyar politikai rendszer - negyedszázad után. Budapest, Osiris-MTA TK, 401-422.

Körösényi András (2017): Weber és az Orbán-rezsim: plebiszciter vezérdemokrácia Magyarországon. Politikatudományi Szemle, 26 (4), 7-28.

Levitsky, Steven-Lucan A. Way (2002): The Rise of Competitive Authoritarianism. Journal of Democracy, 13 (1), 51-65. https://doi.org/10.1353/jod.2002.0026

Levitsky, Steven - Lucan A. Way (2010): Competitive Authoritarianism. Hybrid Regimes After the Cold War. Cambridge University Press. https://doi.org/10.1017/CBO9780511781353

Merkel, Wolfgang (2004). Embedded and Defective Democracies. Democratization, 11 (1) 33-58. https://doi.org/10.1080/13510340412331304598

Morlino, Leonardo (2004): Good and bad democracies: how to conduct research into the quality of democracy. Journal of Communist Studies and Transition Politics, 20 (1), 5-27. https://doi.org/10. 1080/13523270410001687082

Møller, Jørgen-Svend-Erik Skaaning (2010): Beyond the Radial Delusion: Conceptualizing and Measuring Democracy and Non-democracy. International Political Science Review, 31 (3) 261283. https://doi.org/10.1177/0192512110369522 
Munck, Gerardo L.-Jay Verkuilen (2002): Conceptualizing and Measuring democracy - Evaluating Alternative Indices. Comparative Political Studies, 35 (1) 5-34. https://doi.org/10.1177/001041400 203500101

Ringen, Stein (2011): The Measurement of Democracy: Towards a New Paradigm. Society, February, 12-16. https://doi.org/10.1007/s12115-010-9382-7

Sartori, Giovanni (1970): Concept Misformation in Comparative Politics. The American Political Science Review, 64 (4), 1033-1053. https://doi.org/10.2307/1958356

Schedler, Andreas (2002): Elections Without Democracy: The menu of Manipulation. Journal of Democracy, 13 (2), 36-50. https://doi.org/10.1353/jod.2002.0031

Schedler, Andreas (2013): The politics of uncertainty. Sustaining and subverting electoral authoritarianism. Oxford, Oxford University Press. https://doi.org/10.1093/acprof:oso/9780199680320.001.0001

Schumpeter, Joseph (2003): Capitalism, Socialism, and Democracy. London, Routledge, 250-283.

Steiner, Nils D. (2014): Comparing Freedom House Democracy Scores to Alternative Indices and Testing for Political Bias: Are US Allies Rated as More Democratic by Freedom House? Journal of Comparative Policy Analysis, 18 (4), 329-349. https://doi.org/10.1080/13876988.2013.877676

Szűcs Zoltán (2018): Mi a jelentősége annak, hogy Magyarországon jelenleg kompetitív autoriter rezsim van? Ellensúly, 2018.12.21.

Tilly, Charles (2007): Democracy. New York, Cambridge University Press. https://doi.org/10.1017/ cbo9780511804922

Tóka Gábor (2018): A centrális erőtér bomlása. In: Böcskei Balázs-Szabó Andrea (szerk.): Várakozások és valóságok. Parlamenti választás 2018. Budapest, Napvilág-MTA TK, 78-101.

Tóth István János (2019): Magyarországon éppen egy modern autokrácia jön létre. 444.hu, 2019. 01. 26. https://tldr.444.hu/2019/01/26/magyarorszagon-eppen-egy-modern-autokracia-jon-letre (az interjút Magyari Péter készítette)

Tóth Gábor Attila (2016): Demokrácia és diktatúra között: az autoritarizmus. Fundamentum, 2016 (2-4), 5-18.

Unger Anna (2018): A választás mint rendszerkarakterisztikus intézmény. Fundamentum, 2018 (23): 5-16.

Völkel, Jan Claudius (2015): Complex Politics in Single Numbers? The Problem of Defining and Measuring Democracy. Middle East Critique, 24 (1), 67-81. https://doi.org/10.1080/19436149.2014. 998923 